\title{
ENDOSCOPIC EVALUATION OF PATIENTS WITH DYSPEPSIA IN A TERTIARY CARE HOSPITAL: A PROSPECTIVE STUDY
}

Samir Ranjan Nayak¹, Ganni Bhaskara Rao², Dillip Kumar Soren³, Jagdish Kiran Appaka ${ }^{4}$

1 Professor, Department of Surgery, GSL Medical College.

${ }^{2}$ Professor, Department of Surgery, GSL Medical College.

${ }^{3}$ Assistant Professor, Department of Surgery, GSL Medical College.

${ }^{4}$ Senior Resident, Department of Surgery, GSL Medical College.

ABSTRACT

\section{BACKGROUND}

Dyspepsia is a common presentation among the individuals attending the medical or surgical outpatient department to the general hospitals. The dietary habits, food pattern, socioeconomic status made the symptoms of dyspepsia more prevalent in rural and semi-urban areas.

\section{MATERIALS AND METHODS}

The prospective study was conducted at a general hospital for the patients with complaints of dyspepsia.

\section{RESULTS}

Epigastric discomfort and the postprandial fullness are the common symptoms of dyspepsia. The spicy food, smoking and habits of alcohol intake are the important causes of dyspepsia.

\section{CONCLUSION}

The patient with dyspepsia who are older than 50 years of age and/or those with alarm features should undergo endoscopic evaluation.

\section{KEYWORDS}

Dyspepsia, Gastroscope, Postprandial Fullness, Alarming Symptoms.

HOW TO CITE THIS ARTICLE: Nayak SR, Rao GB, Soren DK, et al. Endoscopic evaluation of patients with dyspepsia in a tertiary care hospital: a prospective study. J. Evolution Med. Dent. Sci. 2016;5(40):2418-2421, DOI: 10.14260/jemds/2016/563

\section{INTRODUCTION}

Dyspepsia is a common symptom among individuals seeking medical care that affect one-fourth of populations all over the world.[1] The symptom complex includes upper abdominal pain or discomfort, postprandial fullness, bloating, belching, early satiety, anorexia, nausea, heartburn and occasional vomiting.[2] In absence of any underlying pathologies such as peptic ulcer, reflux disorder, pancreaticobiliary tract disease, dyspepsia is defined as functional dyspepsia.

Objectives of this study were: (1) To study the clinical presentation of patients reporting with dyspeptic symptoms, (2) To establish the cause of dyspepsia by endoscopic examination, (3) To correlate the endoscopic findings with the clinical data, (4) To correlate the histological reports with endoscopic findings.

\section{MATERIALS AND METHODS}

This prospective study was conducted in the Department of General Surgery from the period of January 2013 to June 2013. The patients above 18 years of either sex referred for Upper GI Endoscopy from the Department of General Surgery/Medicine were included in the study group. The

Financial or Other, Competing Interest: None.

Submission 23-02-2016, Peer Review 31-03-2016,

Acceptance 06-04-2016, Published 17-05-2016.

Corresponding Author:

Dr. Samir Ranjan Nayak,

QR No. 407, Staff Quarter

GSL Medical College NHS,

Lakshmipuram, RJMY.

E-mail: drsamirnayak@gmail.com

DOI: $10.14260 /$ jemds $/ 2016 / 563$ clinical presentation, diagnosis, drug treatment and duration of symptoms were noted. Informed consent was obtained from the patient.

The patients with one or more of the following three symptoms were taken into the study group: (1) Post-prandial fullness, (2) Early satiety, (3) Epigastric pain or burning.

\section{The Study Group Excludes following Groups of Patients}

(1) With known dysphagia or malignancy, (2) The patients with prior history of upper GI surgery or radiation, (3) Refusal to give consent, (4) Patients on NSAID within one month of the study.

Complete haemogram, viral screening, abdominal sonogram was done in all cases. Patient was advised fasting for 4-6 hours before the upper GI scope. For all patients Xylocaine spray was used to anaesthetize the pharynx. Gastroscope was performed in left lateral position using Pentax video endoscope with 11 French scopes. Biopsy taken from the ulcer/growth found during scopy. Findings of endoscopy were described.

\section{RESULTS}

During the above period, total 86 patients were enrolled for study group. The baseline parameters were recorded and listed in (Table I).

\begin{tabular}{|c|c|c|c|c|}
\hline $\begin{array}{c}\text { Age } \\
\text { (Years) } \\
\text { (Mean } \pm \text { SD) }\end{array}$ & $\begin{array}{c}\text { Pulse/min } \\
\text { (Mean } \pm \text { SD) }\end{array}$ & $\begin{array}{c}\text { SBP } \\
\text { (mmHg) } \\
\text { (Mean } \pm \text { SD) }\end{array}$ & $\begin{array}{c}\text { DBP } \\
\text { (mmHg) } \\
\text { (Mean } \pm \text { SD) }\end{array}$ & $\begin{array}{c}\text { Hb\% } \\
\text { (Mean } \pm \text { SD) }\end{array}$ \\
\hline $45 \pm 16$ & $77 \pm 6$ & $121 \pm 14$ & $78 \pm 7.7$ & $11 \pm 2$ \\
\hline \multicolumn{6}{|c|}{ Table I: Baseline Parameters of the Dyspeptic Patients } \\
\hline
\end{tabular}


Regarding the sex incidence in study group, males were having more dyspeptic symptoms than females (Table II).

\begin{tabular}{|c|c|c|}
\hline Sex & Number of Cases & Percentage \\
\hline Male & 54 & 62.79 \\
\hline Female & 32 & 32.70 \\
\hline \multicolumn{2}{|c|}{ Table II: Sex Incidence of Dyspeptic Patients } \\
\hline
\end{tabular}

The clinical presentations of the study group before the gastroscope were listed in Table III.

\begin{tabular}{|c|c|c|}
\hline Symptoms & Number of Cases & Percentage \\
\hline Epigastric pain & 51 & 59.3 \\
\hline Postprandial fullness & 44 & 51.16 \\
\hline Early satiety & 15 & 17.44 \\
\hline Anorexia/nausea & 14 & 16.27 \\
\hline Wt. Loss & 09 & 10.46 \\
\hline GI bleed & 14 & 16.27 \\
\hline Dysphagia & 23 & 26.74 \\
\hline \multicolumn{2}{|c|}{ Table III: Clinical Presentation of } \\
the Dyspepsia Patients \\
\hline
\end{tabular}

\section{History of Alcohol/Smoking/Spicy Food}

The individuals who are included in the study have been accustomed to take mixed diet, most of them are of regular habit of consuming spicy food; $70 \%$ males in the study group are habituated with alcohol intake. Three female patients are having habit of reverse smoking. Oesophagitis are found to be common in the individuals with intake of spicy food.

\section{Stool Examination}

Occult blood found to be positive only in six cases, out of which three cases presented with gastrointestinal bleed. Abdominal sonogram was done for all the cases. In majority of cases, the sonogram was normal study (Table IV).

\begin{tabular}{|c|c|c|}
\hline Examination Findings & Number of Cases & Percentage \\
\hline Normal study & 69 & 8023 \\
\hline Fatty liver & 05 & 5.81 \\
\hline Hepatomegaly & 03 & 3.48 \\
\hline Splenomegaly & 04 & 4.65 \\
\hline Cirrhotic changes & 04 & 4.65 \\
\hline ?Mets in liver & 1 & 1.16 \\
\hline Table IV: USG Abdomen Findings of Dyspeptic Patients \\
\hline
\end{tabular}

All the dyspeptic patients were subjected for gastroscope. The findings were noted in Table V.

\begin{tabular}{|c|c|c|}
\hline $\begin{array}{c}\text { Endoscopic } \\
\text { Findings }\end{array}$ & $\begin{array}{c}\text { Number } \\
\text { of Cases }\end{array}$ & Percentage \\
\hline Normal study & 29 & 33.72 \\
\hline Peptic ulcer disease & 18 & 20.93 \\
\hline Oesophagitis & 17 & 19.76 \\
\hline Oesophageal varices & 05 & 5.51 \\
\hline Postcricoid web & 06 & 6.97 \\
\hline Growth/ulcer biopsy & 11 & 12.79 \\
\hline Table V: Endoscopic Findings of Dyspeptic Patients \\
\hline
\end{tabular}

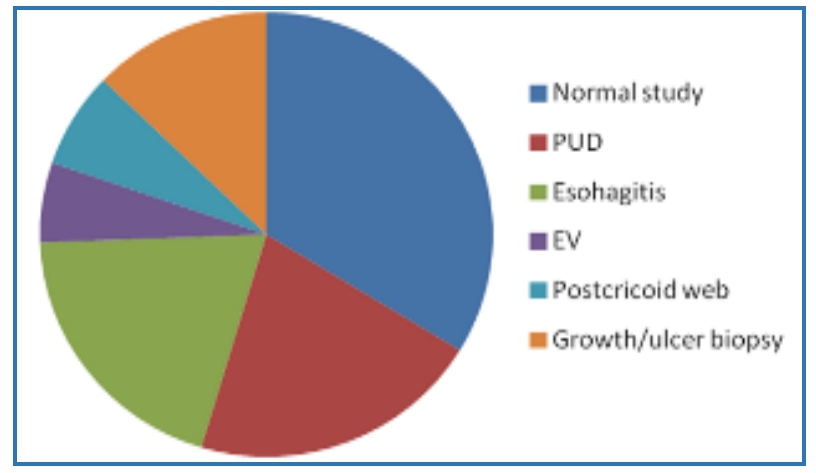

\begin{tabular}{|c|c|c|}
\hline $\begin{array}{l}\text { Endoscopic } \\
\text { Findings }\end{array}$ & $\begin{array}{l}\text { Number } \\
\text { of Cases }\end{array}$ & Percentage \\
\hline Postcricoid webs & 6 & 26.08 \\
\hline Postcricoid growth & 2 & 8.69 \\
\hline Oesophagitis & 6 & 26.08 \\
\hline Growth Oesophagus & 1 & 4.34 \\
\hline Duodenal ulcer & 2 & 8.69 \\
\hline Normal study & 6 & 26.08 \\
\hline \multicolumn{3}{|c|}{$\begin{array}{l}\text { Table VII: Correlation between Dyspepsia and Dysphagias } \\
\text { Alarming Symptoms }(n=23) \text { with Endoscopic Findings }\end{array}$} \\
\hline
\end{tabular}

\begin{tabular}{|c|c|c|}
\hline $\begin{array}{l}\text { Structures } \\
\text { Involved }\end{array}$ & $\begin{array}{l}\text { Endoscopic } \\
\text { Findings }\end{array}$ & $\begin{array}{c}\text { Histological } \\
\text { Findings }\end{array}$ \\
\hline $\begin{array}{l}\text { Postcricoid } \\
\text { Growth } \\
(n=3)\end{array}$ & $\begin{array}{c}\text { Growth } \\
\text { hypopharynx } \\
(n=3)\end{array}$ & $\begin{array}{c}\text { Squamous cell } \\
\text { carcinoma }(n=3)\end{array}$ \\
\hline $\begin{array}{l}\text { Oesophagus } \\
(n=6)\end{array}$ & $\begin{array}{c}\text { Upper } \\
\text { oesophagus }(n=1) \\
\text { Middle } \\
\text { oesophagus }(n=3) \\
\text { Lower } \\
\text { oesophagus }(n=2)\end{array}$ & $\begin{array}{c}\text { Squamous cell } \\
\text { carcinoma }(n=4) \\
\text { Adenocarcinoma } \\
(n=1) \\
\text { Normal } \\
\text { epithelium }(n=1)\end{array}$ \\
\hline $\begin{array}{l}\text { Stomach/ } \\
\text { duodenum } \\
\quad(n=4)\end{array}$ & $\begin{array}{c}\text { Body and antrum } \\
\qquad(\mathrm{n}=3) \\
\text { Pylorus }(\mathrm{n}=1)\end{array}$ & $\begin{array}{l}\text { Adenocarcinoma } \\
(\mathrm{n}=3) \\
\text { Benign gastric } \\
\text { ulcer }(\mathrm{n}=1)\end{array}$ \\
\hline \multicolumn{3}{|c|}{$\begin{array}{c}\text { Table VIII: Correlation between Endoscopic Findings and } \\
\text { Histological Findings (No. of Cases } n=86, \\
\text { Endoscopy done } n=86, \text { Specific Findings Suggestive of } \\
\text { Squamous/Adenocarcinoma/Benign Ulcer } n=13, \\
\text { Other/Normal Findings n=73) }\end{array}$} \\
\hline
\end{tabular}

Table no. 7 shows in the study protocol the individuals having dyspeptic symptoms with dysphagia, as alarming symptoms are having either postcricoid growth or oesophageal growth. Most of the oesophageal malignancies are squamous cell carcinoma.

\begin{tabular}{|c|c|}
\hline Intervention During Endoscopy & Number of Cases \\
\hline Dilatation & 06 \\
\hline Biopsy & 13 \\
\hline Sclerotherapy/EVL & 05 \\
\hline Table IX: The Intervention Done during Endoscopy \\
\hline
\end{tabular}

\section{SUMMARY}

Total 86 cases of dyspeptic patients were studied. Routine blood investigation, USG abdomen, stool examination, upper GI endoscopy was done in all 86 cases; 29 cases were found to be normal study. 
Peptic ulcer disease (Duodenal ulcer, antral gastritis, duodenal ulcer with deformity) found in 18 cases. Postcricoid web was found in 6 cases for which dilatation was done with Savary-Gilliard oesophageal dilators. These patients were advised for follow-up endoscope after 1 month. Oesophageal varices noticed in 5 cases and EVL (Oesophageal variceal ligation) was done. Post procedures, patients are reevaluated for portal hypertension.

These patients were advised for regular followup. Ulcer/growth was found in the postcricoid or oesophagus or in the stomach during endoscopy in 13 cases. Biopsy taken from the ulcer/growth and sent for the histopathological examination. Out of the 13 cases, two cases were found to be benign ulceration. All biopsies (Total Number 3) from postcricoid region were found to be squamous cell carcinoma. Oesophageal growth/ulceration present in 6 cases, 4 are squamous cell carcinoma, 1 case is adenocarcinoma and in 1 case the report came as normal epithelium. Biopsy from stomach done in 4 cases, 3 cases are adenocarcinoma and from 1 case the HPE report came as inflammatory gastric ulcer for which repeat biopsy was done. After getting the histopathology report of proven malignancy, the patients were referred to the cancer hospital for further evaluation.

\section{DISCUSSION}

Dyspeptic symptoms usually includes epigastric discomfort, bloating, anorexia, early satiety, belching or regurgitation, nausea and heartburn.[4,5] The symptoms of dyspepsia most commonly results from 1 of the 4 underlying disorders: peptic ulcer disease, GERD, functional disorders (Non-ulcer Dyspepsia), malignancy. The other abdominal conditions that mimic dyspeptic symptoms are pancreatico-biliary tract diseases, medication intolerance, motility disorders. [6]

The Rome III Committee defined dyspepsia as one or more of the following three symptoms - 1-Postprandial fullness, 2-Early satiety, 3-Epigastric pain or burning.[6] Malignancy is present in $1 \%$ to $3 \%$ of patients with dyspepsia and peptic ulcer disease in another $5 \%$ to $15 \% .[7,8,9,10]$ Endoscopy offers the potential for early diagnosis of structural disease.

\section{The Alarm Features with Dyspeptic Symptoms are}

1. Age 50 yrs. with new-onset symptoms.

2. Family history of upper GI malignancy.

3. Unintended weight loss.

4. GI bleeding or iron deficiency anaemia.

5. Progressive dysphagia.

6. Odynophagia.

7. Persistent vomiting.

8. Palpable mass abdomen.

9. Lymphadenopathy.

10.Jaundice.

Patients with alarm features and dyspepsia have significantly worse outcomes than the normal population. It is worth noting that one-fourth of patients with malignancy and dyspepsia has no alarm symptoms. ${ }^{[7,8]}$

In the study protocol, males were found to have more dyspeptic symptoms with an average age group of 45 years. Epigastric discomfort was the most common clinical presentation followed by the postprandial fullness. In our study protocol, dysphagia was the most common alarming symptoms than upper GI bleed. Spicy food intake is the cause of most of the dyspeptic symptoms. Haemoglobin percentages are found to be within normal range in dyspeptic patients. Patient with alarming symptoms like dysphagia and GI bleed are having low haemoglobin level. Stool for occult blood test positive was found in cases that are having gastrointestinal bleed as the alarming symptoms or duodenal ulcer as a finding in endoscopy.

Ultrasound abdomen done as a routine investigation in the study. Positive findings like splenomegaly correlates with oesophageal varices in endoscopy.

$33.72 \%$ of cases in the dyspeptic patients are having normal endoscopy findings. Only 19.76 patients are having oesophagitis and peptic ulcer disease found in $20.93 \%$ of cases. The findings like hypopharynx and oesophagus growth (Postcricoid webs, postcricoid growth and oesophageal malignancy) is more in the study group because of the high incidence of dysphagia as the alarming symptoms.[11,12,13,14]

\section{CONCLUSIONS}

Indications for endoscopy ultimately needs to be tailored according to the clinical presentation of dyspepsia. A normal endoscopy of dyspepsia cannot be dismissed as irrelevant. Reassurance provided by normal findings may subsequently result in fewer symptoms.[14]

Dyspeptic symptoms, which have a high prevalence and incidence in the population, are the most frequent reason for requesting for an upper endoscopy. It is not uncommon for any young patient with simple dyspepsia to be investigated. The uncertainty regarding which patients with dyspepsia should undergo upper endoscopy is not clear and needs further clarification.

\section{REFERENCES}

1. Chiba N. Definition of dyspepsia: time for a reappraisal. Eur J Surg Suppl 1998;583(583):14-23.

2. Malfertheiner P. Current concepts in dyspepsia: a world perspective. Eur J Gastroenterol Hepatol 1999;11(1):25-9.

3. Westbrook JI, Talley NJ, McIntosh JH, et al. Prevalence of dyspepsia in NSW: a pilot survey. J Gastronterol Hepatol 1997;12:A103.

4. Holtmann G, Stanghellini V, Talley NJ. Nomenclature of dyspepsia, dyspepsia subgroups and functional dyspepsia: clarifying the concepts. Baillieres Clin Gastroenterol 1998;12(3):417-33.

5. Tack J, Talley NJ, Camilleri $M$, et al. Functional gastroduodenal disorders. Gastroenterology 2006;130(5):1466-79.

6. Talley NJ, Vakil NB, Moayyedi P. American gastroenterological association technical review on the evaluation of dyspepsia. Gastroenterology 2005;129(5):1756-80.

7. Wai CT, Yeoh KG, Ho KY, et al. Diagnostic yield of upper endoscopy in Asian patients presenting with dyspepsia Gastrointest Endosc 2002;56(4):548-51.

8. Vakil N, Moayyedi P, Fennerty MB, et al. Limited value of alarm features in the diagnosis of upper gastro intestinal malignancy: systemic review and meta-analysis. Gastroenterology 2006;131(2):390-401. 
9. Fransen GA, Janssen MJ, Muris JW, et al. Meta-analysis: the diagnostic value of alarm symptoms for upper gastrointestinal malignancy. Aliment Pharmacol Ther 2004;20(10):1045-52.

10. Moyyedi P, Talley NJ, Fennerty MB, et al. Can the clinical history distinguish between organic and functional dyspepsia? JAMA 2006;295(13):1566-76.

11. Dooley CP, Larson AW, Stace NH, et al. Double contrast barium meal and upper gastrointestinal endoscopy a comparative study. Ann Intern Med 1984;101(4):538-45.
12. Longo WE, Zucker KA, Zdon MJ, et al. Detection of early gastric cancer in an aggressive endoscopy unit. Am Surg 1989;55(2):100-4.

13. Williams B, Luckas M, Ellinghan JHM, et al. Do young patients with dyspepsia need investigation? Lancet 1988;332(8624):1349-51.

14. Rabeneck L, Wristers K, Souchek J, et al. Impact of upper endoscopy on satisfaction in patients with previously uninvestigated dyspepsia. Gastrointest Endosc 2003;57(3):295-9. 